\title{
Evolution of University Third Mission Activities in Slovakia: What Role for a Public Policy?
}

DOI: 10.12776/QIP.V23I1.1165

\author{
Štefan Rehák, Miroslav Šipikal, Alexandra Lešková
}

Received: 23 September 2018 Accepted: 10 February 2019 Published: 31 March 2019

\begin{abstract}
Purpose: Universities are an important component of regional innovation systems. There have been a number of studies during recent years in developed countries which analysed activities of universities aiming to increase their contribution in regional innovation. The aim of this article is to explore the evolution of third mission activities of universities in Slovakia and explore the role of public policy in this process.
\end{abstract}

Methodology/Approach: We used a document analysis of annual reports of all public universities in Slovakia to see which third mission activities universities claim to perform and how the situation has changed over the years. We also compared universities according to their focus and location. Several personal and telephone interviews were conducted to verify or supplement the information.

Findings: We found that among all third mission activities, the greatest change was observed in research and cooperation activities with businesses. This mainly resulted from a change in government policy but mostly due to very strong support from EU structural funds.

Research Limitation/implication: The study is based on annual reports of universities which do not necessarily cover all activities that universities actually perform.

Originality/Value of paper: The paper provides the first complete overview of the third mission activities performed by universities in Slovakia with a focus on their development over time. Also, it identifies the role which governmental policy plays in these processes.

Category: Research paper

Keywords: universities; research; innovations; Slovak Republic; third mission of universities 


\section{INTRODUCTION}

The increasing dependence of advanced economies on the use of new knowledge and new technologies has changed the requirements for higher education. As a result, universities introduced a set of new activities which supplement traditional educational and research missions of universities with more active participation in socio-economic development (Molas-Gallart et al., 2002; Boucher, Conway and Van der Meer, 2003; Laredo, 2007; Caniëls and Van den Bosch, 2011; Trippl, Sinozic and Lawton Smith, 2015; Kroll, Dornbusch and Schnabl, 2016). This movement is generally known as the third mission of universities.

In this paper, we focus mainly on the third mission activities aiming to increase regional innovation capabilities. While there is relatively extensive research on the third mission activities in developed countries, research in post-socialist countries is rather limited. Experience from post-socialist countries offer a great opportunity to study the role of framework conditions for university third mission activities. Rather dynamic changes in countries' economies in a relatively short time accompanied with dramatic institutional changes resulted in paradigmatic transformation of the mission of universities in these countries. This allows to investigate the evolution of such activities and the role of public policy in this process.

Slovakia belongs to a group of countries with a high level of economic growth but low innovation performance. After joining the EU under the influence of cohesion policy, Slovakia has put a greater emphasis on investing in education and research infrastructure and in building mechanisms to increase efficiency of knowledge transfer from universities. The aim of this article is to explore the development of the third mission activities of universities in Slovakia in the context of changing public policies. The authors assume that the changing economic and institutional environment in Slovakia has resulted in more targeted, formalized and institutionalized activities of universities.

The authors would like to answer two questions: Which universities' activities have begun to be implemented as their third mission research activities? How did the higher education policy affect implementation of such universities' activities? Current research in post-socialist countries has focused mainly on the analysis of the framework conditions in the field of higher education and less on the activities of universities themselves. Compared to similar studies that have the nature of cross-sectional studies, this article also looks at the time dimension of this process. This allowed the authors to evaluate the extent to which universities have begun to implement their activities, and to evaluate the influence of policy measures on these activities. 


\section{THE ROLE OF UNIVERSITIES IN REGIONAL DEVELOPMENT AND CLASSIFICATION OF THEIR ACTIVITIES}

Trippl, Sinozic and Lawton Smith (2015) identify four theoretical concepts which provide a framework for analysing the third mission activities and their contribution to economic and social development, namely the Entrepreneurial University model (Etzkowiz et al., 2000), the Regional Innovation Systems (RIS) model (Braczyk, Cooke and Heidenreich, 1998), the Mode 2 model and the Engaged University model (Uyarra, 2010; Breznic and Feldman, 2012). What these concepts have in common is that they emphasize the importance of active and targeted diffusion of the knowledge of universities among other actors. Several authors attempted to identify and classify these activities (Molas-Gallart et al., 2002; Boucher, Conway and Van der Meer, 2003; Laredo, 2007; European Commission, 2011; Caniël and Van den Bosch, 2011; Kroll, Dornbusch and Schnabl, 2016). Authors divide them into three broad areas - education, research and community development (e.g. Caniëls and Van den Bosch, 2011). A substantial part of empirical research is mainly concerned with activities related to university research as these are expected to have a major impact on long-run economic development (Gunasekara, 2006; Vallance et al., 2017). These activities aim at increasing research collaboration between universities and firms (e.g. contract research, innovation vouchers), activities that support innovative entrepreneurship (e.g. technology incubators, spin-off and start-up support) and finally, commercialisation of intellectual property and equipment (e.g. licensing office).

The most comprehensive study of universities in 14 regions across seven EU countries by Boucher, Conway and Van der Meer (2003) found that the activities of universities might vary depending on the type of the host region (economic structure, location) and the university type (focus, size, age). Most active universities tend to be single and relatively large scale universities located in peripheral regions (Boucher, Conway and Van der Meer, 2003). In these regions, universities are unique partners for local actors, so their engagement level is higher. However, Gunasekara (2006) pointed out that their ability to respond to external needs is overestimated. On the other hand, traditional universities in metropolitan regions have significant engagement mostly at an international level. Kroll, Dornbusch and Schnabl (2016) noticed that university activities in developed regions are mainly driven by regional opportunities, while in the lagging regions rather by political order.

Engagement of universities is significantly determined by individual decisions of academics. Research in Germany on a sample of 1,500 academics (Kroll, Dornbusch and Schnabl, 2016) confirmed that choices to engage are strongly contingent on intrinsic motivations. Goldstein, Bergman and Maier (2013) compared the attitudes of academics in the US and the EU and also confirmed that individual factors explain the greatest differences in attitudes towards university activities in the field of research commercialisation and regional 
development. Both studies, however, also pointed out that framework conditions play a significant role.

Differences in university activities between individual countries but also between regions within countries are influenced by the overall institutional context (Trippl, Sinozic and Lawton Smith, 2015). In their paper, (Trippl, Sinozic and Lawton Smith, 2015) call for more scholarly work in order to understand the effect of a larger set of policies (research policy, education policy, industrial policy etc.) on university activities. Regional involvement rate can be also positively influenced by a higher degree of decentralization of competencies in higher education at the regional level (Boucher, Conway and Van der Meer, 2003). The change in the funding of universities towards multi-source funding as well as the regionalization of policies, result in even greater interconnection with local and regional interests (Chatterton and Goddard, 2000).

Post-socialist countries offer a great opportunity to study the evolution of third mission activities under changing institutional contexts. The process of commercialization of intellectual property may be different and more complicated than in developed countries (Etzkowitz et al., 2000). Universities in post-socialist countries have a different position in innovation systems compared to universities in Western European countries (Rehák and Sokol, 2007; Gál and Páger, 2017). Innovation systems in Central and Eastern Europe have been characterized by higher degree of fragmentation, low levels of cooperation and a lack of intermediary organizations (Rehák and Sokol, 2007; Radosevic, 2002; Serbanica, Constantin and Dragan, 2015; Kwiek, 2012). Empirical research in Czechia (Krčmářová, 2011) showed that the first university activities were mainly focused on establishing offices for communication and knowledge transfer. However, majority of such offices only passively distributed information on research expertise. Research in Hungary (Gál and Páger, 2017), Poland (Kwiek, 2012), Romania (Serbanica, Constantin and Dragan, 2015) and Czechia (Krčmářová, 2011; Žížalová and Čadil, 2012) showed that a lack of incentives for cooperation and missing systemic support are still a typical issue in Central and Eastern Europe. European research and innovation policies played a major role in enhancing research activities and intermediary infrastructure (Ptáček and Sczyrba, 2017); and establishing systematic linkages in the regional innovation system (Vallance et al., 2017).

\section{HIGHER EDUCATION SYSTEM IN THE SLOVAK REPUBLIC AND ITS CHANGES}

Transformation of higher education in the Slovak Republic started in the early 1990s by granting academic freedoms and autonomy in decision-making. After 2000, public universities have been transformed from state budget organizations to independent public institutions. They acquired their own assets and a multisource funding system has been introduced (Matlovič and Matlovičová, 2017). Public funding has been gradually transformed from being based primarily on the 
number of students to a system taking into account also other activities of universities. For instance, the state provides $50 \%$ of university funding based on their research activities. (Pisár and Šipikal, 2017). There has also been expansion of higher education in the regions of the Slovak Republic. This brought a more even distribution of universities across the country and moderated the dominance of the Bratislava region. At the beginning of the 1990s, about a half of university students studied in the Bratislava region. This number dropped to $38 \%$ in 2016. As of 2016, there were 35 universities with 129 faculties operating in Slovakia. Of the 35 universities, 20 institutions were public (105 faculties), 12 were private (18 faculties) and 3 were state universities (6 faculties).

In 2015, the share of universities in total Slovak research and development (R\&D) expenditure reached 44\%, while in 2002 this share was less than $10 \%$ (see Fig. 1 for annual development). The massive increase in the share of research and development universities' expenditure was mainly related to Slovakia's entry into the EU in 2004 and the use of cohesion funding. Accession to the EU has brought greater opportunities for universities to raise funds from the EU structural funds in order to improve their technological equipment, renovate buildings and fund research activities, particularly outside of the Bratislava region. The total volume of resources contracted to support research from the EU structural funds in the programming period 2007-2013 for universities was over 860 million EUR, which in some years accounted for more than $20 \%$ of the total resources of universities (Pisár and Varga, 2018).

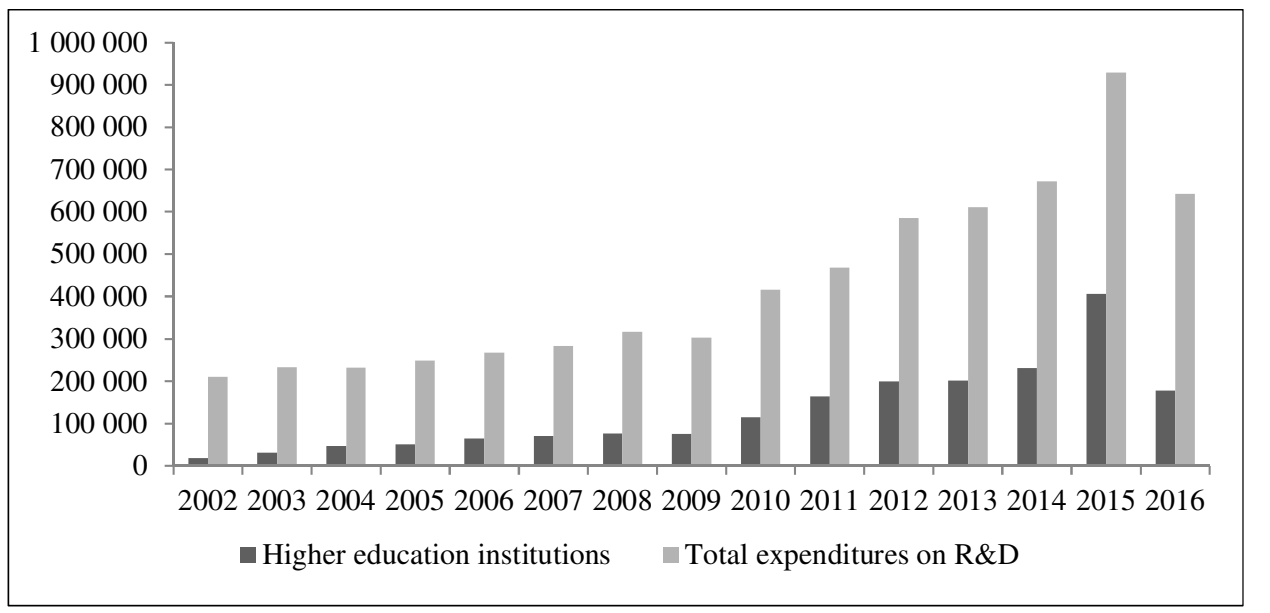

Figure 1 - Expenditure on Research and Development in Slovakia during 2002-2016 (in Thousand EUR in Current Prices)(Own Compilation based on Data from the Statistical Office of the Slovak Republic, DataCube)

In the area of education, the overall amount was much lower at about 92 million EUR (Šipikal, Pisár and Varga, 2015). The main areas of support are summarized in Tab. 1. The new programming period is even more focused on research activities. However, the first activities of universities funded from the 
programming period 2014-2020 have only begun to be implemented in 2017, so the annual reports that we evaluate do not capture them.

Table 1 - Overview of Support Measures for Universities from the Structural Funds in the Programming Period 2007-2013 for Research and Development (www.nsrr.sk, all activities were Supported from Operational Programme Research and Development)

\begin{tabular}{|c|c|c|}
\hline Measure & $\begin{array}{l}\text { Total funds } \\
2007-2013 \text { in } \\
\text { EUR for } \\
\text { universities }\end{array}$ & Specific objective \\
\hline 1.1 . & $41,006,432.33$ & $\begin{array}{l}\text { Modernisation and improvement of quality of technical } \\
\text { infrastructure for research and development in } 2007-2013 \\
\text { with a view to increase the ability of research and } \\
\text { development institutions to efficiently cooperate with } \\
\text { renowned research institutions in the EU and other countries, } \\
\text { as well as with entities of the social and economic practice } \\
\text { through the transfer of knowledge and technologies. }\end{array}$ \\
\hline 2.1 . & $108,385,148.80$ & $\begin{array}{l}\text { Increase the quality of research organisations and support to } \\
\text { excellent research activities with emphasis placed on areas of } \\
\text { strategic importance for the further development of the } \\
\text { economy and the society. }\end{array}$ \\
\hline 2.2 . & $291,377,531.90$ & $\begin{array}{l}\text { Increase the level of cooperation of R\&D institutions with the } \\
\text { society and economy through the transfer of knowledge and } \\
\text { technology, thereby facilitating economic growth of the } \\
\text { regions and of whole Slovakia. }\end{array}$ \\
\hline 4.1. & $33,756,888.20$ & $\begin{array}{l}\text { Increase the quality of research organisations and support of } \\
\text { excellent research activities in the Bratislava region with an } \\
\text { emphasis placed on areas of strategic importance for the } \\
\text { further development of the economy and the society. }\end{array}$ \\
\hline 5.1. & $97,370,104.63$ & $\begin{array}{l}\text { Improving the quality of education at universities by investing } \\
\text { in material infrastructure. The purpose of the measure is } \\
\text { investment activities aimed at the reconstruction and } \\
\text { expansion of college buildings and/or the modernization of } \\
\text { their interior facilities in order to improve the conditions in } \\
\text { which the education process takes place in universities, with } \\
\text { the priority being to modernize the internal equipment of the } \\
\text { universities. }\end{array}$ \\
\hline
\end{tabular}

\section{METHODOLOGY AND DATA}

Universities in the Slovak Republic are of three types: public, state and private. Research of this paper focuses only on 20 public universities. In order to explore the third mission of universities, the authors focused primarily on public universities because they accommodate $90 \%$ of all university students and have the obligation to publish annual reports that were the main source of information for this research. 
The period for exploring the third mission of universities in Slovakia was 20082016. We chose this period for three reasons. Firstly, universities had an opportunity to use EU structural funds for the first time in the programming period 2007-2013, which was subsequently extended to 2015. The first funds started to be used in 2008 (Šipikal and Némethová, 2017b). Secondly, there were substantial changes made in universities' funding, which took place primarily during 2009-2012 and which had a significant effect on their behaviour (Pisár and Sipikal, 2017). Thirdly, the idea of the third mission concept started to be more intensively discussed in the Slovak Republic after 2008 (Hanová et al., 2016).

The aim of our research was to identify how the Slovak universities third mission research activities have changed over time and to analyse what role public policy has played in this process. We also looked at whether different types of universities responded to these policies differently. We consider a third mission research activity as a concrete and implemented activity mentioned in an annual report of a university that concerned the relevant area under review.

The paper compared universities according to their focus (technical and nontechnical) and location (universities in the Bratislava region and other Slovak regions). Based on the literature review, in case of technical universities, we assumed that there would be a stronger commitment to research and entrepreneurial activities than in non-technical universities in the field of education and community development. We also assumed that universities located outside of the Bratislava region would have a greater connection to the region's activities. The overview of universities and their structure is shown in Tab. 2.

Table 2 - List and Characteristics of Universities (Own Compilation)

\begin{tabular}{|l|c|r|r|r|}
\hline University & Type & Region & \multicolumn{1}{c|}{$\begin{array}{c}\text { Number of } \\
\text { students } \\
\mathbf{( 2 0 1 6 )}\end{array}$} & $\begin{array}{c}\text { Research } \\
\text { grants in } \\
\text { EUR (2016) }\end{array}$ \\
\hline $\begin{array}{l}\text { Comenius University } \\
\text { in Bratislava }\end{array}$ & Non - technical & Bratislava & 23,305 & $9,885,297$ \\
\hline $\begin{array}{l}\text { Slovak University of } \\
\text { Technology in } \\
\text { Bratislava }\end{array}$ & Technical & Bratislava & 11,496 & $10,171,108$ \\
\hline $\begin{array}{l}\text { University of } \\
\text { Economics in } \\
\text { Bratislava }\end{array}$ & Non - technical & Bratislava & 7,453 & $2.430,188$ \\
\hline $\begin{array}{l}\text { Academy of } \\
\text { Performing Arts in } \\
\text { Bratislava }\end{array}$ & Non - technical & Bratislava & 1,016 & 401,626 \\
\hline $\begin{array}{l}\text { Academy of Fine Arts } \\
\text { in Bratislava }\end{array}$ & Non - technical & Bratislava & 620 & 402,693 \\
\hline
\end{tabular}




\begin{tabular}{|c|c|c|c|c|}
\hline University & Type & Region & $\begin{array}{c}\text { Number of } \\
\text { students } \\
(2016)\end{array}$ & $\begin{array}{c}\text { Research } \\
\text { grants in } \\
\text { EUR }(2016)\end{array}$ \\
\hline $\begin{array}{l}\text { University of Trnava } \\
\text { in Trnava }\end{array}$ & Non - technical & Trnava & 122 & $1,039,565$ \\
\hline $\begin{array}{l}\text { University of } \\
\text { Constantinus the } \\
\text { Philosopher in Nitra }\end{array}$ & Non - technical & Trnava & 8,994 & $1,742,432$ \\
\hline $\begin{array}{l}\text { Selye János University } \\
\text { in Komárno }\end{array}$ & Non - technical & Trnava & 1,732 & 805,849 \\
\hline $\begin{array}{l}\text { Slovak University of } \\
\text { Agriculture in Nitra }\end{array}$ & Technical & Nitra & 8,248 & $3,697.190$ \\
\hline $\begin{array}{l}\text { University of St. Cyril } \\
\text { and Methodius of } \\
\text { Trnava }\end{array}$ & Non - technical & Nitra & 6,174 & 639,445 \\
\hline $\begin{array}{l}\text { Alexander Dubček } \\
\text { University of Trenčín } \\
\text { in Trenčín }\end{array}$ & Non - technical & Trenčín & 2,700 & 686,736 \\
\hline $\begin{array}{l}\text { Matej Bel University } \\
\text { in Banská Bystrica }\end{array}$ & Non - technical & Banská Bystrica & 9,042 & $1,720,535$ \\
\hline $\begin{array}{l}\text { Technical University } \\
\text { in Zvolen }\end{array}$ & Technical & Banská Bystrica & 3,481 & $1,572,802$ \\
\hline $\begin{array}{l}\text { Academy of Arts in } \\
\text { Banská Bystrica }\end{array}$ & Non - technical & Banská Bystrica & 545 & 179,839 \\
\hline $\begin{array}{l}\text { University of Žilina in } \\
\text { Žilina }\end{array}$ & Technical & Žilina & 8,792 & $6,289,258$ \\
\hline $\begin{array}{l}\text { Catholic University in } \\
\text { Ružomberok }\end{array}$ & Non - technical & Žilina & 4,107 & 545,609 \\
\hline $\begin{array}{l}\text { University of Prešov } \\
\text { in Prešov }\end{array}$ & Non - technical & Prešov & 9,216 & $1,501,666$ \\
\hline $\begin{array}{l}\text { Technical University } \\
\text { of Košice }\end{array}$ & Technical & Košice & 9,713 & $4,427,017$ \\
\hline $\begin{array}{l}\text { Pavol Jozef Šafárik } \\
\text { University in Košice }\end{array}$ & Non - technical & Košice & 7,480 & $3,474,562$ \\
\hline $\begin{array}{l}\text { University of } \\
\text { Veterinary Medicine } \\
\text { in Košice }\end{array}$ & Non - technical & Košice & 2,130 & 847,540 \\
\hline
\end{tabular}

We primarily used document analysis, in particular annual reports of universities. The advantage of this method over others (e.g. interviews) is that the documents were created at a given time and are unchangeable, reflecting the priorities of the institution at the time. In interviews, participants can tailor responses to the current requirements of their activities (Bowen, 2009). The annual reports of individual universities for years 2008 and 2016 which are available on their 
websites form the basis of data collection. In three cases, there were no annual reports available for year 2008. Thus, we worked with the documents from 2009. It is the case of Pavol Jozef Šafárik University in Košice, Selye János University in Komárno and University of Constantinus the Philosopher in Nitra. We also conducted several personal and telephone interviews to verify or supplement the information from the annual reports. Stating these activities in annual reports highlighted their strategic importance and their institutional acceptance. Hence, it is possible to distinguish between an important or systematic activity and an activity implemented on a random or personal basis.

The literature review of the paper has already identified that the third mission activities of universities could be analysed in three main dimensions - education, research and community development. The authors focused on research activities, which have changed most dramatically (see Tab. 3). In the field of research, the paper focused mainly on the three key areas of "third mission" defined by Hanová et al. (2016) in their report for the Ministry of Education.

Table 3 - Number of Universities with Third Mission Activities in the Specific Area (Own compilation)

\begin{tabular}{|c|c|c|}
\hline & 2008 & 2016 \\
\hline \multicolumn{3}{|l|}{ Education domain } \\
\hline Matching the needs of the regional labour market & 11 & 12 \\
\hline Increasing participation of local inhabitants in education & 17 & 19 \\
\hline Retaining graduates in the region & 0 & 0 \\
\hline Supporting entrepreneurial activity in the region & 3 & 6 \\
\hline \multicolumn{3}{|l|}{ Research domain } \\
\hline $\begin{array}{l}\text { Increasing the cooperation between universities and regional } \\
\text { companies }\end{array}$ & 10 & 15 \\
\hline Promoting innovative enterprises in the region & 3 & 7 \\
\hline Commercialization of intellectual property and equipment & 0 & 4 \\
\hline \multicolumn{3}{|l|}{ Community development domain } \\
\hline Increasing civil participation in the region & 3 & 8 \\
\hline $\begin{array}{l}\text { Improving facilities for cultural and sports infrastructure in the } \\
\text { region }\end{array}$ & 20 & 20 \\
\hline Demonstration activities & 0 & 2 \\
\hline
\end{tabular}




\section{RESULTS}

Research activities related to the third mission of universities have not been at the forefront of interest of Slovak universities for a long time. The government policy attempted to change it by an increase of its weight in the system of financing of universities in the Slovak Republic (Šipikal and Némethová, 2017a). The second important moment was the entry of Slovakia into the EU, which gave universities the opportunity to use EU structural funds for these activities. As part of this research, we were first interested in how the activities of universities in this area have changed; and second, what role the government policies have played in these changes.

Cooperation of universities and companies in research existed at the beginning of the observed period, especially in the case of technically oriented universities and universities in the Bratislava region. However, during the observed period, it was not only the increase of research activities that was important, but some improvement has been made also in the creation of systems for the continuous and systematic activities of universities. Based on data collected from interviews, most of collaboration had been based on personal contacts until the EU structural funds were available. Later on, these funds were mainly used to gradually create specialized departments or centres that led to greater interconnection of research with practice. Many of these activities were supported through structural funds, particularly through special measures 2.1 and 4.2 of the OP Research and Development - Transfer of knowledge and technology acquired through research and development into practice with more than 386 million EUR allocated. Within these measures, technical universities obtained more than $60 \%$ of all funds (for the entire period 2007-2013) and universities from Bratislava more than $47 \%$ of all funds. These results suggest strong abilities to use this measure in these two categories of universities.

Several centres of excellence, science centres or science parks were created at universities with the support of the EU structural funds. There was a specific measure in the Operational Programme Research and Development to support such activities with more than 280 million EUR allocated. For example, Slovak University of Technology in Bratislava "STU Scientific" is responsible for commercialization of research and founding of joint ventures. Other examples can be found at the university science park of the Technical University of Košice - "Technikon"; a joint project of two Košice's universities "Medipark"; the science park of the University of Žilina; the establishment of the Comenius University "Science Park" and many others. Almost all these systematized forms of support have arisen at technically oriented universities or faculties. In the field of social and human sciences, this cooperation was still based primarily on personal contacts of individual researchers. Hence, cooperation is substantially less developed than in technically oriented universities. Also, there was no other similar activity implemented without the EU support. 
Table 4 - Number of Universities with Third Mission Activities in Research (Thematic and Regional Perspective) (Own Compilation)

\begin{tabular}{|c|c|c|c|c|c|c|c|c|c|c|}
\hline & \multicolumn{2}{|c|}{$\begin{array}{c}\text { All } \\
\text { universities } \\
\text { (20) }\end{array}$} & \multicolumn{2}{|c|}{$\begin{array}{c}\text { Non - } \\
\text { technical } \\
\text { (15) }\end{array}$} & \multicolumn{2}{|c|}{$\begin{array}{c}\text { Technical } \\
\text { (5) }\end{array}$} & \multicolumn{2}{|c|}{$\begin{array}{l}\text { Bratislava } \\
\qquad \text { (5) }\end{array}$} & \multicolumn{2}{|c|}{$\begin{array}{c}\text { Rest of } \\
\text { Slovakia } \\
\text { (15) }\end{array}$} \\
\hline & 2008 & 2016 & 2008 & 2016 & 2008 & 2016 & 2008 & 2016 & 2008 & 2016 \\
\hline \multicolumn{11}{|c|}{ Increasing the cooperation between universities and regional companies } \\
\hline $\begin{array}{l}\text { Joint research } \\
\text { projects with } \\
\text { regional } \\
\text { companies }\end{array}$ & 8 & 14 & 5 & 9 & 3 & 5 & 2 & 4 & 6 & 10 \\
\hline $\begin{array}{l}\text { Contracted } \\
\text { research }\end{array}$ & 1 & 3 & 0 & 1 & 1 & 2 & 0 & 0 & 1 & 3 \\
\hline $\begin{array}{l}\text { Consultancy } \\
\text { services }\end{array}$ & 3 & 3 & 2 & 2 & 1 & 1 & 0 & 1 & 3 & 2 \\
\hline $\begin{array}{l}\text { Mobility of } \\
\text { workers } \\
\text { between firms } \\
\text { and } \\
\text { universities }\end{array}$ & 0 & 0 & 0 & 0 & 0 & 0 & 0 & 0 & 0 & 0 \\
\hline \multicolumn{11}{|c|}{ Promoting innovative enterprises in the region } \\
\hline $\begin{array}{l}\text { Support for } \\
\text { academic spin } \\
\text { off companies }\end{array}$ & 1 & 6 & 0 & 3 & 1 & 3 & 1 & 2 & 0 & 4 \\
\hline $\begin{array}{l}\text { Technological } \\
\text { incubators }\end{array}$ & 1 & 3 & 0 & 1 & 1 & 2 & 1 & 2 & 0 & 1 \\
\hline $\begin{array}{l}\text { Science and } \\
\text { technology } \\
\text { parks }\end{array}$ & 1 & 7 & 1 & 4 & 0 & 3 & 0 & 2 & 1 & 5 \\
\hline \multicolumn{11}{|c|}{ Commercialization of intellectual property and equipment } \\
\hline $\begin{array}{l}\text { Intellectual } \\
\text { property } \\
\text { licensing }\end{array}$ & 0 & 0 & 0 & 0 & 0 & 0 & 0 & 2 & 0 & 2 \\
\hline $\begin{array}{l}\text { Commercial } \\
\text { use of } \\
\text { facilities }\end{array}$ & 0 & 2 & 0 & 1 & 0 & 1 & 0 & 1 & 0 & 1 \\
\hline $\begin{array}{l}\text { Non-academic } \\
\text { dissemination }\end{array}$ & 0 & 1 & 0 & 1 & 0 & 0 & 0 & 1 & 0 & 0 \\
\hline
\end{tabular}

Cooperation has also grown due to EU projects. For example, in 2016, a call for joint research projects of enterprises and universities was launched. It attracted 200 applicants with 62 projects supported in a total value of 300 million EUR. This strong demand also points at progressively more active engagement with 
business and also shows that there is still room and capacity of universities for more active engagement in this area.

Although research cooperation is much more intense than in the past, the commercial nature of this collaboration, which would have a greater impact on the university and the region, is still largely missing. Most of the cooperation so far has been based on joint projects, mostly supported by EU structural funds. Direct contracted research as an expression of direct business interest in the skills and knowledge of universities is still very scarce and with comparable lower budget. There are also no systems for the commercialization of research. These work only partially in some technically oriented universities. However, only little attention is being paid to them in the annual reports. In 2008, there was no mention of commercialization activities in any annual report of the universities. Intellectual property licensing basically does not exist and probably because of the very low patent activity of universities. However, the situation has also moved forward in this area. Under a project supported by the EU structural funds, a national technology transfer centre has been established, which has signed contracts with seven of the most active universities. They have established university technology transfer centres which are gradually organizing activities in the field of commercialization of research. For example, at the University of Žilina, the Center in 2016 prepared internal guidelines that regulate mechanisms for the management of intellectual property, creating the first premise for systematic work on commercialization of research. The centre also addresses implementation of technology transfer (intellectual property protection and commercialization). Its aim is to create and achieve a long-term self-financing and sustainable system of technology transfer support through the establishment and operation of the Joint Patent Fund. Similar centres were created at the Slovak University of Agriculture in Nitra and at Slovak University of Technology in Bratislava which are both technically oriented universities.

Technical equipment of the universities has also partially improved with the support of the EU structural funds. This resulted in higher demand from private companies in the commercial use of university assets. For example, Comenius University in Bratislava declares that the science park has contracts with 160 researchers who are involved in the research activities of the park or use the park infrastructure for their research. However, it is not clear how many of them are external subjects and other researchers of the university.

In the area of support of entrepreneurship, only few of the most important universities are active - most of them technology oriented. Only three universities have their own operating incubators and some of them offer courses in business skills. The oldest one is the Slovak University of Technology Technological Incubator, which has supported more than 50 incubated companies through the InQb program. Technical University of Košice had 5 companies in its incubator in 2016. Support of entrepreneurship is aimed at supporting own students rather than developing the region in which they operate. The aforementioned incubators are also more likely to encourage creation of 
start-ups capable to compete on a national or international level rather than to support the establishment of businesses that would meet regional needs. This was the only activity where universities were more active even in the absence of EU support funding.

\section{DISCUSSION AND CONCLUSION}

The movement of universities towards fulfilling their third mission is a typical feature not only in Western countries, but this paper confirmed such a trend also in Slovakia. Comparison of different activities of Slovak public universities in three domains, namely education, research and community development, showed interesting results. The majority of universities are engaged in three main types of activities - activities aimed at increasing participation of local inhabitants in education; increasing cooperation between universities and companies; and improving facilities for sports and culture. While in the education and community domain only minor changes can be observed during 2008 and 2016, activities of universities in the research domain increased substantially.

The most significant change can be observed in joint activities with businesses such as joint research projects, contracted research and in activities which aim to promote innovative entrepreneurship. The main reason for this is a change in government policy in this area. Government has significantly strengthened the position of research, obtained grants and research activities directly connected to practise. A specific factor for improving the activities within the third mission of universities was support from the EU structural funds. The volume of these funds was extremely high when looking at the total funding of universities, the value of individual projects often reached almost the annual budget of the respective university. Demand of the universities for these resources has exceeded the possibilities of public support. Thus, this indicates there is still room for an increase in the volume of activities in this area. In addition, the need for project sustainability in combination with a large volume of resources have often led to the development of system solutions through which specialized institutions have been established with clearly defined long-term tasks.

However, the real effects of these activities may be observed only over a longer period. Some studies point to the possible effect of building a "cathedral in the desert" (Huňady, Orviská and Šarkanová, 2014). While the universities have significantly intensified cooperation with the private sector, no major increase in the number of patents or licenses was recorded. This may indicate low efficiency of these activities. High demand for public resources is usually accompanied with the problem of rent-seeking. Especially as the amount of co-financing from universities was only at 5\% level. There are also areas where universities are not systematically involved, such as promoting worker mobility or non-academic dissemination of results. Again, this could be caused by a lack of government support in these areas. 
Generally, we can contend that government policy has significantly influenced the behaviour of universities. Many other studies (Abramo, Cicero and D' Angelo 2011; Pisár and Šipikal, 2017) confirmed that universities to a large extent adapt their actions to the conditions set for funding by the government. Since public universities are financed mainly from public sources and the private sector has a very small share in higher education, universities are more likely to respond to government activities than to the needs of companies. This is especially the case of activities that are associated with high fixed costs in the initial phase (e.g. technology parks). It seems that in countries with low innovation performance, such as Slovakia, government support can be a key factor in the launch of new research activities or networks.

Different focus on the third mission activities can also be seen among different types of universities. The results show a significantly higher orientation of technical universities for research and cooperation with companies. This may be caused by the country's high industrial orientation and stronger demand of this sector for these activities. The activities that universities carried out with EU support would have probably been implemented only to a very limited extent or not at all, without public financial support. Diversity of activities differs with the size of universities. Largest universities have the widest range of activities. On the other side, unlike some other studies (Boucher, Conway and Van der Meer, 2003) pointed out, there is no significant difference between universities in developed and less-developed regions. However, this may be the result of strong EU support for less developed regions. Compared to developed countries, we have not seen a more prominent role of local and regional governments, which is probably due to concentration of competences in the field of Slovak higher education at a national level.

\section{ACKNOWLEDGEMENTS}

This contribution was supported by the Slovak Research and Development Agency (APVV), APVV-14-0512 "Universities and regional development" and by VEGA, grant no. 1/0605/19 "New role of universities in regional innovation systems".

\section{REFERENCES}

Abramo, G., Cicero, T. and D'Angelo, C.A., 2011. The dangers of performancebased research funding in non-competitive higher education systems. Scientometrics, 87(3), pp.641-654.

Boucher, G., Conway, C. and Van der Meer, E., 2003. Tiers of engagement by universities in their region's development. Regional studies, 37(9), pp.887-897.

Bowen, G.A., 2009. Document analysis as a qualitative research method. Qualitative research journal, 9(2), pp.27-40. 
Braczyk, H.J., Cooke, P.N. and Heidenreich, M., 1998. Regional innovation systems: the role of governances in a globalized world. London: Psychology Press.

Breznitz, S.M. and Feldman, M.P., 2012. The engaged university. The Journal of Technology Transfer, 37(2), pp.139-157.

Caniëls, M.C. and Van den Bosch, H., 2011. The role of higher education institutions in building regional innovation systems. Papers in Regional Science, 90(2), pp.271-286.

Chatterton, P. and Goddard, J., 2000. The Response of Higher Education Institutions to Regional Needs. European Journal of Education, 35(4), pp.475496.

Etzkowitz, H., Webster, A., Gebhardt, C. and Terra, B.R.C., 2000. The future of the university and the university of the future: evolution of ivory tower to entrepreneurial paradigm. Research policy, 29(2), pp.313-330.

European Commission, 2011. Connecting Universities to Regional Growth: A Practical Guide. [pdf] s.l., s.n.. Available at: $<$ https://ec.europa.eu/regional_policy/sources/docgener/presenta/universities2011 /universities2011_en.pdf> [Accessed 08 September 2018].

Gál, Z. and Páger, B., 2017. The changing role of universities and the innovation performance of regions in Central and Eastern Europe. In: G. Lux and G. Horváth, 2017. The Routledge Handbook to Regional Development in Central and Eastern Europe. London: Routledge. Ch. 14.

Goldstein, H., Bergman, E.M. and Maier, G., 2013. University mission creep? Comparing EU and US faculty views of university involvement in regional economic development and commercialization. The Annals of regional science, 50(2), pp.453-477.

Gunasekara, C., 2006. Reframing the Role of Universities in the Development of Regional Innovation Systems. The Journal of Technology Transfer, 31(1), pp.101-113.

Hanová, M., Moravčíková, D., Rehák, Š. and Vozár, L., 2016. Posilnenie úlohy vysokých škôl v regiónoch. Bratislava: Ministerstvo školstva, vedy, výskumu a športu Slovenskej republiky.

Huňady, J., Orviská, M. and Šarkanová, B., 2014. Determinants of European Firm's Innovation and the Role of Public Financial Support. European Financial and Accounting Journal, 9(1), pp.62-84.

Krčmářová, J., 2011. The third mission of higher education institutions: conceptual framework and application in the Czech Republic. European Journal of Higher Education, 1(4), pp.315-331. 
Kroll, H., Dornbusch, F. and Schnabl, E., 2016. Universities' Regional Involvement in Germany: How Academics' Objectives and Opportunity Shape Choices of Activity. Regional Studies, 50(9), pp.1595-1610.

Kwiek, M., 2012. Universities, regional development and economic competitiveness: The Polish case. In: R. Pinheiro, P. Benneworth and G. Jones, 2012. Universities and Regional Development. A Critical Assessment of Tensions and Contradictions. New York: Routledge. pp.69-85.

Laredo, P., 2007. Revisiting the third mission of universities: Toward a renewed categorization of university activities?. Higher education policy, 20(4), pp.441456.

Matlovič, R. and Matlovičová, M., 2017. Neoliberalization of the higher education in Slovakia: a geographical perspective. Geografický Časopis, 69(4), pp.313-337.

Molas-Gallart, J., Salter, A., Patel, P., Scott, A. and Duran, X., 2002. Measuring third stream activities, Final Report to the Russell Group of Universities. Brighton: SPRU, University of Sussex.

Pisár, P. and Šipikal, M., 2017. Negative Effects of Performance Based Funding of Universities: The Case of Slovakia. NISPACEE Journal of Public Administration and Policy, 10(2), pp.155-171.

Pisár, P. and Varga, M., 2018. Public Support for Higher Education Institutions from EU Structural Funds and its Evaluation: Case Study of Slovakia. NISPAcee Journal of Public Administration and Policy, 11(2), pp.103-127.

Ptáček, P. and Sczyrba, Z., 2017. The role of Universities in Strengthening Innovation: the case of EU structural funds in the Czech Republic. Geograficky časopis, 69(4), pp.339-360.

Radosevic, S., 2002. Regional innovation systems in Central and Eastern Europe: determinants, organizers and alignments. The Journal of Technology Transfer, 27(1), pp.87-96.

Rehak, S. and Sokol, M., 2007. Regional pathways towards the knowledge economy: experiences from Slovakia. In: K. Piech, 2007. Knowledge and Innovation Processes in Central and East European Economies. Warsaw: The Knowledge and Innovation Institute. pp.228-246.

Serbanica, C.M., Constantin, D.L. and Dragan, G., 2015. University-Industry Knowledge Transfer and Network Patterns in Romania: Does Knowledge Supply Fit SMEs' Regional Profiles?. European Planning Studies, 23(2), pp.292-310.

Šipikal, M. and Némethová, V., 2017a. Výkonové financovanie univerzít prípadová štúdia Slovenska. Scientific Papers of the University of Pardubice. Series D, Faculty of Economics \& Administration, 25(41), pp.169 -180. 
Šipikal, M. and Némethová, V., 2017b. EU cohesion policy-booster or destroyer of national policies? Case of universities. Research Papers of the Wroclaw University of Economics, (466), pp.203-212.

Šipikal, M., Pisár, P. and Varga, M., 2015. Verejná podpora a financovanie univerzít. Finančná stabilita a udržatelný rast v Európskej únii: súčasný stav a perspektívy. Banská Bystrica: Belianum.

Trippl, M., Sinozic, T. and Lawton Smith, H., 2015. The role of universities in regional development: conceptual models and policy institutions in the UK, Sweden and Austria. European Planning Studies, 23(9), pp.1722-1740.

Uyarra, E., 2010. Conceptualizing the regional roles of universities, implications and contradictions. European Planning Studies, 18(8), pp.1227-1246.

Vallance, P., Blažek, J., Edwards, J. and Květoň, V., 2017. Smart specialisation in regions with less-developed research and innovation systems: A changing role for universities?. Environment and Planning C: Politics and Space, [e-journal] 36(2), pp.219-238. https://doi.org/10.1177/2399654417705137.

Žižalová, P. and Čadil, V., 2012. Universities, researchers and their perspective on the fulfilment of the third role. In: R. Capello, A. Olechnicka and G. Gorzelak, 2012. Universities, cities and regions: loci for knowledge and innovation creation. Oxon: Routledge. pp.246-267.

Annual reports of all investigated universities of years 2008 and 2016.

\section{ABOUT AUTHORS}

Štefan Rehák - Associate Professor, University of Economics in Bratislava. E-mail: stefan.rehak@euba.sk.

Miroslav Šipikal - Associate Professor, University of Economics in Bratislava. E-mail: miroslav.sipikal@euba.sk.

Alexandra Lešková - Ph.D. Candidate, University of Economics in Bratislava. E-mail: alexandra.leskova@euba.sk.

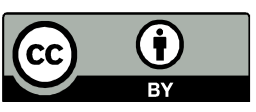

(C) 2019 by the authors. Submitted for possible open access publication under the terms and conditions of the Creative Commons Attribution (CC-BY) license (http://creativecommons.org/licenses/by/4.0/). 